\title{
IMPLEMENTATION ANALYSIS OF SEKOLAH SIAGA KEPENDUDUKAN (SSK) IN EAST JAVA 2019
}

\author{
Aliqul Abdiyah ${ }^{1}$, Fonny Indri Hartanti², Yuly Sulistyorini ${ }^{3}$ \\ ${ }^{1,3}$ Department of Biostatistics and Population, Faculty of Public Health, Universitas Airlangga, 60115 Surabaya, \\ East Java, Indonesia \\ ${ }^{2}$ National Board of Population and Family Planning Representative of East Java Province, 60286 Surabaya, \\ East Java, Indonesia \\ Corresponding Author: Aliqul Abdiyah \\ E-mail: aliqul.abdiyah-2017@fkm.unair.ac.id
}

\begin{abstract}
One of the ways to synergize various parties in anticipating and overcoming problems as a result of population dynamics is to increase the role of teachers through the establishment of Sekolah Siaga Kependudukan (SSK). This study aims to analyze the implementation of the SSK in East Java in 2019. The analysis was using descriptive analysis method. Secondary data on the number of schools that have SSK program is obtained through the area of population control by National Board Population and Family Planning Representative in East Java. Primary data related to problems and solutions in schools associated with the implementation of the SSK program were obtained by in-depth interviews conducted with heads of sub-fields and staff working in the area of Population Control. In 2017, National Board of Population and Family Planning Representative of East Java initiated the formation of SSK in 3 districts and cities. From 2017 to August 2019, the number of schools in East Java that have participated in the SSK program were 58 Senior High Schools and 24 Junior High Schools. Only 20.8\% of schools that have met the SSK's criteria of success, namely (1) have a decree on the formation (2) have a nameplate, (3) the establishment of a population corner, (4) the integration of population material on subjects in the form of Lesson Plan (LP), and (5) community-related activities. Implementing SSK program in East Java still needs to be improved, especially in forming population corner. Students follow the integration of SSK materials into school subjects and the presence of population-themed activities through advocacy and coordination with stakeholders in districts and cities. The SSK program also requires increased socialization of activities at schools.
\end{abstract}

Keywords: sekolah siaga kependudukan, population education, knowledge

\section{ABSTRAK}

Salah satu upaya untuk mensinergikan berbagai pihak dalam mengantisipasi dan mengatasi permasalahan sebagai akibat dinamika kependudukan adalah meningkatkan peran guru melalui pembentukan Sekolah Siaga Kependudukan (SSK). Penelitian ini memiliki tujuan untuk menganalisis bagaimana pelaksanaan SSK di Provinsi Jawa Timur tahun 2019. Analisis pada penelitian ini menggunakan metode analisis deskriptif. Data sekunder jumlah sekolah yang memiliki SSK didapatkan melalui bidang pengendalian penduduk Perwakilan BKKBN Provinsi Jawa Timur. Data primer terkait permasalahan dan solusi di sekolah terkait pelaksanaan program SSK di Provinsi Jawa Timur diperoleh dengan cara wawancara mendalam yang dilakukan kepada kepala sub bidang dan staff yang bekerja di bidang Pengendalian Penduduk. Pada tahun 2017, Perwakilan BKKBN Provinsi Jawa Timur menginisiasi terbentuknya SSK di 3 kabupaten/kota. Dari tahun 2017 sampai dengan bulan Agustus 2019, jumlah sekolah di Provinsi Jawa Timur yang sudah mengikuti program SSK sebanyak 58 SMA/sederajat dan 24 SMP/sederajat. Hanya 20,8\% sekolah yang sudah memenuhi kriteria standar keberhasilan SSK, yaitu (1) mempunyai surat keputusan pembentukan (2) memiliki papan nama, (3) terbentuknya pojok kependudukan, (4) adanya integrasi materi kependudukan pada mata pelajaran dalam bentuk Rencana Pelaksanaan Pembelajaran (RPP), dan (5) adanya kegiatan bertema kependudukan. Pelaksanaan program SSK di Jawa Timur masih perlu ditingkatkan khususnya dalam hal pembentukan pojok kependudukan, integrasi materi SSK ke dalam mata pelajaran di sekolah dan adanya kegiatan bertema kependudukan yang diikuti oleh siswa melalui advokasi dan koordinasi dengan pemangku kepentingan di kabupaten/kota serta meningkatkan fasilitasi kegiatan di sekolah.

Kata kunci: sekolah siaga kependudukan, pendidikan kependudukan, pengetahuan 


\section{INTRODUCTION}

The CIA World Factbook states that Indonesia ranks fourth in world's largest population with total $260,580,739$ people, or $3.51 \%$ of the total world population in 2017 . East Java's population is the second largest in Indonesia, with 39.5 million people. This increasing number of population can cause changes in the distribution, composition, and age structure of the society itself.

The increasing number of population requires more attention, especially if the proportion of teenagers and productive age people is higher in number. According to the projection of East Java's population in 20112020, the population in East Java is dominated by people in productive age (15-64 years) of $69.54 \%$. East Java is currently in a demographic bonus where two people of productive age have less than one person of productive age dependents. This demographic bonus demands the preparation of a high-quality generation, which must start with teenagers who are currently at school, which is done by providing an understanding of the population. Information or education obtained by someone, especially teenagers, can have a good influence on increasing knowledge, including population knowledge (Diniyati and Jayatmi, 2017). By understanding the population, it is expected that young generation will make proper planning in the future. The plan includes further education on family planning (Ma'arif, 2018). For this reason, it is necessary to establish Sekolah Siaga Kependudukan (SSK) in schools. The purpose of this study was to analyze the implementation of SSK in East Java in 2019.

\section{METHODS}

This study used descriptive analysis research design. This study analyzed the implementation of the SSK program in East Java in 2019. Secondary data on the number of schools that have SSK was obtained through the area of population control from National Board of Population and Family Planning Representative of East Java. Primary data related to problems in schools and solutions made by National Board of Population and Family Planning Representative of East Java related to the implementation of the SSK program in East Java were obtained by in-depth interviews conducted with heads of sub-fields and staff working in Population Control.

The indicators used to analyze the implementation of SSK were the first Formation Decree and the SSK nameplate in front of the school. Second, the formation of population corner in schools. Third, the SSK nameplate is placed in front of the schools. Fourth, the integration of population material in subjects in the form of lesson plan. Fifth, there are population-themed activities enrolled by the students.

SSK analysis was performed using a point award system with answer scores "Yes $=1$ " and "No $=0$ " on each indicator of the SSK's success. At the point number of subjects, each subject integrated with population material gets 1 point, and so on. The total number of points per school can be categorized as follows: final grades 0 to $\leq 4$ are classified as poor and final grades $\geq 5$ are categorized as good. The data obtained from the analysis results are presented in several tables, accompanied by detailed charts and explanations.

\section{RESULT}

Data of senior high schools and junior high schools having SSK program was obtained from the National Board of Population and Family Planning Representative of East Java. Schools that have met the success indicators of the SSK program in East Java are presented in the table 1 .

Table 1. List and Results of Tabulation of Total Points of Senior/Vocational High Schools with SSK Program in 2017-2019

\begin{tabular}{lclc}
\hline \multicolumn{1}{c}{ School Name } & $\begin{array}{c}\text { Year of } \\
\text { Establishment }\end{array}$ & \multicolumn{1}{c}{ School Origin } & $\begin{array}{c}\text { Tabulation } \\
\text { Results }\end{array}$ \\
\hline SMAN 2 Pamekasan & 2017 & Pamekasan (district) & 11 points \\
SMAN 1 Lamongan & 2017 & Lamongan (district) & 4 points \\
SMAN 7 Kota Malang & 2017 & Malang (city) & 8 points \\
SMAN 10 Kota Malang & 2017 & Malang (city) & 8 points \\
MAN 1 Banyuwangi & 2017 & Banyuwangi (district) & 3 points \\
\hline
\end{tabular}




\begin{tabular}{|c|c|c|c|}
\hline School Name & $\begin{array}{c}\text { Year of } \\
\text { Establishment }\end{array}$ & School Origin & $\begin{array}{c}\text { Tabulation } \\
\text { Results }\end{array}$ \\
\hline MAN 1 Bojonegoro & 2017 & Bojonegoro (district) & 10 points \\
\hline SMAN 1 Karangrejo & 2018 & Tulungagung (district) & 4 points \\
\hline SMA Nurul Anwar Montong & 2018 & Tuban (district) & 4 points \\
\hline SMA Asomadiyah Tuban & 2018 & Tuban (district) & 0 points \\
\hline SMA Muhammadiyah* & 2018 & Blitar (city) & 0 points \\
\hline SMAN 1 Karangrejo* & 2018 & Tulungagung (district) & 3 points \\
\hline SMAN 1 Kalidawir & 2018 & Tulungagung (district) & 3 points \\
\hline SMAN 1 Kademangan* & 2018 & Blitar (district) & 0 points \\
\hline SMAN 1 Gurah* & 2018 & Kediri (district) & 0 points \\
\hline SMAN 1 Kandangan* & 2018 & Kediri (district) & 0 points \\
\hline SMAN 1 Kandat* & 2018 & Kediri (district) & 0 points \\
\hline SMAN 1 Wates* & 2018 & Kediri (district) & 3 points \\
\hline SMAN 1 Kepanjen & 2018 & Malang (district) & 1 point \\
\hline SMAN 7 Kediri & 2018 & Kediri (city) & 0 points \\
\hline SMAN 2 Kota Blitar* & 2018 & Blitar (city) & 0 points \\
\hline SMK Veteran $1 *$ & 2018 & Tulungagung (district) & 0 points \\
\hline SMK Kertanegara* & 2018 & Kediri (district) & 0 points \\
\hline SMK Pelayaran Hang Tuah* & 2018 & Kediri (city) & 2 points \\
\hline SMK PGRI 1 Tulungagung & 2018 & Tulungagung (district) & 2 points \\
\hline SMK Islam 1 Durenan & 2018 & Trenggalek (district) & 3 points \\
\hline SMKN 1 Panggungrejo & 2018 & Blitar (district) & 3 points \\
\hline MA Al-Misri* & 2018 & Jember (district) & 0 points \\
\hline MA Bahrul Ulum & 2018 & Probolinggo (district) & 2 points \\
\hline MAN 4 Jombang & 2018 & Jombang (district) & 4 points \\
\hline MAN 2 Pamekasan & 2018 & Pamekasan (district) & 11 points \\
\hline MAN Kota Blitar* & 2018 & Blitar (city) & 0 points \\
\hline SMA Mambaus Sholihin* & 2019 & Blitar (district) & 0 points \\
\hline SMA Ma'arif Terrak & 2019 & Pamekasan (district) & 5 points \\
\hline SMA Katolik Ignatius Slamet Riyadi* & 2019 & Bojonegoro (district) & 0 points \\
\hline SMAN 1 Garum* & 2019 & Blitar (district) & 0 points \\
\hline SMAN 1 Bakung* & 2019 & Blitar (district) & 0 points \\
\hline SMAN 1 Sutojayan* & 2019 & Blitar (district) & 0 points \\
\hline SMAN 1 Situbondo & 2019 & Situbondo (district) & 9 points \\
\hline SMAN 1 & 2019 & Bangkalan (district) & 2 points \\
\hline SMAN 5 Pamekasan & 2019 & Pamekasan (district) & 9 points \\
\hline SMAN 3 Pamekasan & 2019 & Pamekasan (district) & 8 points \\
\hline SMAN 1 Batu & 2019 & Batu (city) & 2 points \\
\hline SMAN 2 Batu & 2019 & Batu (city) & 3 points \\
\hline SMK Muhammadiyah 2 & 2019 & Ponorogo (district) & 1 point \\
\hline SMK YP 17 Lumajang* & 2019 & Lumajang (district) & 0 points \\
\hline SMK PGRI Sooko & 2019 & Mojokerto (district) & 3 points \\
\hline SMK Ma'arif 1 Branta Tinggi & 2019 & Pamekasan (district) & 3 points \\
\hline SMKN 1 Kademangan & 2019 & Blitar (district) & 0 points \\
\hline SMKN 1 Bagor & 2019 & Nganjuk (district) & 2 points \\
\hline SMKN 2 Batu* & 2019 & Batu (city) & 0 points \\
\hline SMKN 1 Bakung* & 2019 & Blitar (district) & 0 points \\
\hline MA Ma'arif Udanawu* & 2019 & Blitar (district) & 0 points \\
\hline MA Sabilul Muttaqin* & 2019 & Bojonegoro (district) & 0 points \\
\hline MA Al-Falah Tlanakan & 2019 & Pamekasan (district) & 6 points \\
\hline MA Darul Akhlak Toronan & 2019 & Pamekasan (district) & 5 points \\
\hline MA Bustanul Ulum Angsanah & 2019 & Pamekasan (district) & 3 points \\
\hline MAN 2 Pasuruan & 2019 & Pasuruan (district) & 5 points \\
\hline MAN 1 Gresik & 2019 & Gresik (district) & 5 points \\
\hline MAN 2 Madiun & 2019 & Madiun (city) & 1 point \\
\hline
\end{tabular}


Table 2. List and Results of Tabulation of Total Points of Junior High Schools with SSK Program in 2017-2019

\begin{tabular}{llll}
\hline \multicolumn{1}{c}{ School name } & \multicolumn{1}{c}{$\begin{array}{c}\text { Year of } \\
\text { Establishment }\end{array}$} & \multicolumn{1}{c}{ School Origin } & $\begin{array}{c}\text { Tabulation } \\
\text { Results }\end{array}$ \\
\hline SMPN 5 Kota Malang & 2017 & Malang city & 8 points \\
SMPN 10 Kota Malang & 2017 & Malang city & 8 points \\
SMPN 21 Kota Malang & 2017 & Malang city & 8 points \\
SMPN 1 Mojo* & 2018 & Kediri District & 0 points \\
SMPN 1 Gampeng* & 2018 & Kediri District & 0 points \\
SMPN 1 Papar* & 2018 & Kediri District & 0 points \\
SMPN 1 Kepung* & 2018 & Kediri District & 0 points \\
SMPN 1 Puncu* & 2018 & Kediri District & 0 points \\
SMPN 1 Pare* & 2018 & Kediri District & 0 points \\
SMPN 1 Ngadiluwih* & 2018 & Kediri District & 0 points \\
SMPN 1 Semen* & 2018 & Kediri District & 0 points \\
SMPN 1 Turen & 2018 & Malang District & 0 points \\
SMPN Krian & 2018 & Sidoarjo District & 2 points \\
SMPN 2 Ngawi & 2018 & Ngawi District & 8 points \\
SMPN 5 Kota Pasuruan* & 2018 & Pasuruan City & 5 points \\
SMP Mambaus Sholihin* & 2019 & Blitar District & 0 points \\
SMPN 2 Kademangan* & 2019 & Blitar District & 0 points \\
SMPN 1 Selorejo* & 2019 & Blitar District & 0 points \\
SMPN 1 Pujer & 2019 & Bondowoso District & 3 points \\
SMPN 1 Batu* & 2019 & Batu City & 0 points \\
SMPN 5 Batu* & 2019 & Batu City & 0 points \\
SMPN 2 Batu & 2019 & Batu City & 2 points \\
MTs Sunan Kalijogo Binangun* & 2019 & Blitar District & 0 points \\
MTsN 4* & 2019 & Blitar District & 0 points \\
\hline
\end{tabular}

Information: * (asterisks) are schools that have fewer points in the category of achievement according to the SSK indicator $\leq 4$

Table 2 lists schools at the junior high school level that have participated in SSK program in East Java, while the number of schools that have taken the SSK program is presented in graphical form as shown in Figure 1.

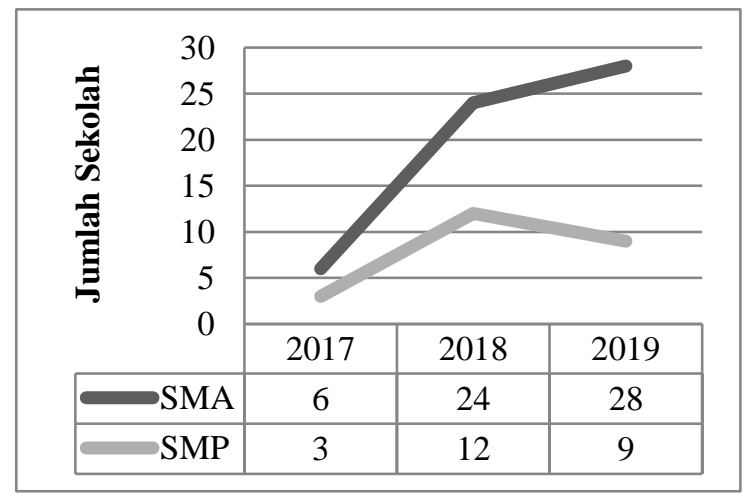

Figure 1. Number of New Schools Participating in the SSK Program in East Java 2017-2019 per JulyAugust
In 2017, 9 schools participated in the SSK program consisting of 6 senior high schools or equivalent and 3 junior high schools or equivalent. In 2018, the number of schools participating in SSK program was increased by 36 schools consist of 24 senior high schools and 12 junior high schools. In 2019, there were 37 schools participated in the SSK program, divided into 28 senior high schools or equivalent and 9 junior high schools until October. The diagram above concludes the number of schools participating in SSK program in East Java was increased from 2017 to 2018 for senior high schools. It continued to develop from 2018 to 2019. Whereas in junior high school, there was a decrease in the number from the year 2018 to 2019.

The cumulative number of high school and junior high schools with the SSK program showed that there were 3 senior high schools and 3 junior high schools in 2017. In 2018, the number of schools participating in the SSK program from the senior high level increased by 
30 schools and in the junior high level increased by 15 schools. Whereas in 2019 around JulyAugust, the number of schools participating in SSK at senior high level also increased by 58 schools, and junior high level by 24 schools.

Cumulative data for junior and senior high school level participating in the SSK program in East Java in percentage is presented in Figure 2.

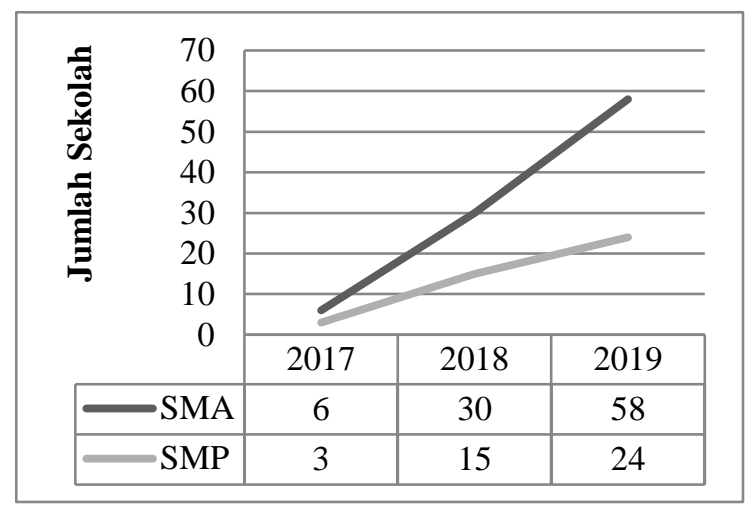

Figure 2. Number of Cumulative Schools Participating in the SSK Program in East Java 2017-2019 per JulyAugust

\section{DISCUSSION}

School is essential since it is the tree of education center that serves to maintain moral values and a foundation on the development that exists in society, including adolescents (Lahmi, 2016). SSK is a school in which there is a combination of Family Planning material, family development, and population education, which are then summarized into several subjects and specific local content of population. In SSK, there is a population corner that functions as a learning place and a source of student knowledge about the population to form family planning (National Board of Population and Family Planning, 2017). The broader function of the population corner is in addition to being a source of information services for students, and it also functions as counseling related to population and reproductive health issues. The population perspective is expected to be an improvement in terms of adolescent knowledge, attitudes, and behavior about the development of population dynamics in Indonesia (Titisari, 2018).

In the implementation of the SSK program, it is necessary to evaluate the implementation of program policies. Implementing a strategy is very important to analyze how successful a plan is. Implementation of an approach can be interpreted as a process of the relationship between actions and objectives that must be implemented (Sabdaningtyas, 2018). The evaluation consists of three main points, namely input in the form of resources that can support the success of a program, a process that includes all actions taken to produce an output, and output in the form of goods or services that are useful for consumers or that implement a program (Rohmatulloh and Shalahuddin, 2014).

The evaluation in this study uses a modification of the policy model of Van Meter and Van Horn which consists of 6 variables, namely (1) necessary measures and objectives of the policy (2) sources of policy (3) communication between organizations implementing activities (4) characteristics of implementing agencies (5) social, economic, political conditions and (6) implementing tendencies (Marsuyetno and Harahap, 2013). Based on the analysis results of the SSK program that has been carried out, the variables used are the necessary size variables and policy objectives, policy sources, and communication between organizational implementation activities.

\section{SSK Input Program}

\section{Basic Measures and Objectives of the Policy}

There are 5 (five) indicators to measure the success of the SSK in East Java, namely (1) the formation of SSK, proved by decree of formation (2) the SSK nameplate in front of the school, (3) the formation of a population corner, (4) the existence of integration population material on subjects in the form of lesson plan (LP), and (5) population-themed activities that are enrolled by students.

\section{Policy Sources}

Policy sources, or commonly called resources, are required to implement policy for supporting the process. Human resources come from staff and head of sub-division in the area of population control who work directly to introduce SSK program to districts and cities' regional apparatus organization (RAO) in East Java, which then passed on to schools in the districts and cities. SSK fund resources come from independent funds by the schools, National Board of Population and Family Planning, and East Java government. The stages 
of SSK development are not the same in each school per region, which depend on the stage of development of each school.

Media provided by National Board of Population and Family Planning related to SSK program is in the form of population-themed materials book which is integrated in the school subject such as the number and population growth, population of teenagers, people in productive age, senior citizens, urbanization, and urban area development (National Board of Population and Family Planning, 2015). In this case, National Board of Population and Family Planning created a module for integrating population material into high school subjects entitled "Non-Text Book on Population Education Integration with Subjects in Senior High School" which contains material about: population explosion and its impact on the lives, adolescents and their problems, social change in the population, employment in economic development, human reproductive organs and sexually transmitted diseases, and quality family (Hasanah and Nadiroh, 2018). At the junior high school level, National Board of Population and Family Planning also created a module to integrate population material into a subject entitled "Integration of Non-Text Book Population Education with Subjects in Junior High Schools." This book contains material about shaping the personality of children and adolescents, adolescents and their development, population, demographic bonuses, and urbanization (Yuliani and Nadiroh, 2018).

The material is included in the lesson plan, which is integrated into subjects in schools. National Board of Population and Family Planning also makes literacy reading books to increase students' knowledge of population material at junior and senior high school levels, with material provided following the student school level. These books can also be accessed from cis.bkkbn.go.id/dalduk/?p=20 link.

The population literacy books, as mentioned above, are usually placed in the population corner. Furthermore, in the population corner also provided tables, graphs, population pyramids, posters, population books, pamphlets, brochures, and others as a source of information in the form of interactive modules containing multimedia elements proven to effectively encourage learning activities for students related to population issues (Nurulwahida et al., 2015). Informations in population corner are mostly presented in the form of photos. Those information are including adolescent reproductive health, population migration, healthy birth delivery, early-age marriages, adulthood marriage, population growth, traffic jams, victims of domestic violence, etc. Population map can be in the form of population distribution, increase, density, migration, age of first marriage, level of family planning participation, quality of human resources, population structure, etc. The graphs are presenting distribution, population growth, density, migration, age of marriage, dependency rate, family planning participation, population composition, maternal mortality rate, infant mortality rate, etc. In addition, there are also population articles, reference books, banners, brochures, bulletins, magazines, banners, films and novels with populationrelated theme, etc.

\section{Process}

\section{Communication between Organizational Implementation Activities}

SSK was formed in East Java in 2017 and has had collaborations in several junior and senior high school levels or equivalent. The number of schools in regencies/cities in East Java that have participated in the SSK program is 58 high schools or equivalent and 24 junior high schools or equivalent from 2017 to JulyAugust 2019.

During the formation phase of the PSS, the activity carried out was the National Board of Population and Family Planning Representative of East Java, who introduced SSK to the regencies and cities in collaboration with the school. Furthermore, issuing a SSK formation and nameplate in front of the school. In SSK implementation phase, the activity carried out is to integrate population material into subjects. This population material is also included in the local content and extracurricular activities in the school. The SSK development phase, the action is undertaken is the establishment of a population corner at the schools. There is no target number per year for the number of schools with the SSK program since in East Java, SSK program is still relatively new. Therefore, SSK program is still in the process of forming a model. The establishment of SSK is minimum one SSK program for one district/city.

Based on interviews with the Population Control and Head of Population Education 
Subdivision, there were some difficulties encountered when running the SSK program from 2017 to 2019. The problem was that most schools in East Java did not know the concept of Sekolah Siaga Kependudukan (SSK) even though it was formed in 2017 by the National Board of Population and Family Planning Representative of East Java. Some schools already have various programs. Therefore, it was not easy to introduce the program, including SSK program, which was established by a Representative of the National Family Planning Coordinating Board in East Java.

One of the SSK indicators is the integration of population-related materials into the school subjects through the lesson plan (LP). However, many schools have difficulty, including inserting population-relation material into the LP, because the curriculum loads on each subject is very numerous and dense. Furthermore, there are also teachers who do not understand the competency for population material.

The difficulty experienced by the East Java Provincial National Board of Population and Family Planning Representative was that during the SSK introduction to the districts or cities in collaboration with the school, the staffs often changed from staff mutations. Therefore, the introduction must be repeated every time there is a staff change, and so on.

The solution to the problem that has been carried out by the National Board of Population and Family Planning Representative of East Java regarding SSK is establishing program in stages. The establishment of the SSK program is adapted to school conditions. First, the step of formation, then the implementation and development of SSK. In addition, socialization should be conducted one to two times regarding the SSK program to increase teenagers' knowledge about the program. The following supporting factors can also influence teenagers' understanding in ethnic identity, social support, and involvement, including characteristics of adolescents themselves, support from families, and how to convey information related to the PSS program for teenagers (Zimmerman et al., 2013). National Board of Population and Family Planning also made a briefing module in the integration of population education for teachers at junior high, religion-based schools and Senior High School.

The solution to the problems from the National Board of Population and Family
Planning Representative of East Java Province, namely to overcome the ever-changing staff mutations. National Board of Population and Family Planning Representatives of East Java Province must carry out monitoring to the districts and cities. They also should always do socialization, which is not only done once during SSK program. This activity is inversely proportional to Krisdayanti and Edyanto (2018) which stated that the function of this staff mutation is nothing but an increase in the work power and usability of a job in a company or organization. In the implementation of this SSK program, staff mutations will hamper the development of the implementation of the SSK in East Java, so that problem solutions become less effective.

\section{The Output}

There were results showing that schools have met the success indicators of SSK program in East Java from the 82 high school and junior high schools mentioned in Table 1 and Table 2. The following are the top 3 schools' ranking with the highest points related to SSK program for the high school level: first, SMA 2 Pamekasan with 11 points in total. SSK program at this school was formed in 2017. In 2019, it already had a formation decree, SSK nameplate, population corner, and subject integration. The total population material is seven subjects including Religious education, PPKn, Mathematics, Physical Education, Biology, Indonesian History, and Geography, and has participated in population-themed activities. Second, Madrasah Aliyah Negeri 2 Pamekasan with a total of 11 points. SSK at this school was formed in 2018. Until 2019, there has been formation decree, nameplate, population corner, and integration of subjects with population material. A total of 7 subjects including Religious education, PPKn, Mathematics, Physical Education, Biology, Indonesian History, and Geography, and have participated in population-themed activities.

The third is SMA 1 Bojonegoro, with a total of 10 points. SSK was formed from 2017, until 2019 already has a formation decree, nameplate, population corner, integration of 5 subjects with population materials (Geography, PPKn, Arts, Health and Physical Sciences), and have participated in population-themed activities. 
At the junior high school level, there are three best schools with a total of 8 points, namely SMP 5 Malang, SMP 10 Malang, SMP 21 Malang, and SMPN Krian. SSK was formed in 2017, until 2019, already has formation decree, nameplate, population corner, integration of subjects with population material with a total of 3 subjects namely Biology, Geography, Mathematics, and has participated in population-themed activities. SMPN Krian with a total of 8 points. SSK was formed from 2018, until 2019 already has a formation decree, nameplate, integration of subjects with population material with a total of 4 subjects (Religion, Science, English, and Counseling Guidance), and has followed populationthemed activities

In addition to the best school ranking for SSK program above, there are several schools with 0 points that fall into the category of inadequate, among others: Senior High School levels totaling 23 schools, mentioned in Table 1 with asterisks, and junior high schools $\mathrm{s}$ completing 16 schools, indicated in Table 2 with asterisks. Schools are categorized as lacking as discussed above because the SSK program is still at the stage of socialization only, and there has been no further development, so it does not meet the SSK indicators in East Java.

Some districts and cities in East Java that do not have SSK program including Pacitan, Madiun, Magetan, Sampang, Sumenep, Probolinggo, Mojokerto, and Surabaya. The data on the number of SSK above was obtained until 2019 per July-August. The latest information as of September-October 2019, all districts and cities have SSK program.

There are already several schools in several districts and cities with a population corner. The senior high school level consisting of MAN 1 Bojonegoro, SMAN 1 Kademangan, SMKN 1 Panggungrejo, MAN 4 Jombang, SMAN 7 Malang, SMAN 10 Malang, SMAN 2 Batu and MAN 1 Gresik. The junior high school level consisting of SMPN 2 Ngawi, SMPN 5 Malang, and SMPN 21 Malang.

Other than those mentioned above, most schools are still in the stage of forming and developing SSK program. Population corner should at least have a data board or board to attach data and photos, the size and location of the population corner at the school match the availability of the situation at the school, as well as the integration of population material in-class learning.
The last point is that there have been several activities participated by students about the population, including a competition held by the school and National Board of Population and Family Planning Representative of East Java with a population theme. These activities include competitions. In making scientific papers, speeches, making short films, contest creations of residents, poster making contests, population case operation contests, etc. In addition, there are extracurricular activities in schools that have been integrated with SSK program such as scouts and PMR.

\section{CONCLUSIONS AND SUGGESTIONS}

\section{Conclusion}

The implementation of the SSK program in East Java still needs to be improved to have a meaningful contribution to internalization of knowledge regarding population issues in daily life and increase awareness, attitudes, and students' behavior management about reproductive health, marriage age, future planning, and quality nuclear family. Some things that still need to be improved include the establishment of a population corner, the integration of SSK material into subjects in schools, and the existence of population-themed activities that are followed by students in schools. Of all SSK programs that have been formed in East Java, only $20.8 \%$ of SKK has carried out activities following the specified success standards.

\section{Suggestion}

There is no evaluation of the PSS program in East Java, so it is necessary to conduct an assessment related to the program. Program evaluation is carried out for consideration in taking policy for applications that are implemented as an effort to improve the programs currently being implemented. Evaluation steps based on indicators of the success of the PSS program, according to the authors, are (a) advocating stakeholders including the regents/mayors, heads of district and city education offices, and coordination with regional government family planning organizations for the formation of SSK and integration of SSK material into subjects in schools (b) increase the socialization of the SSK program to schools to expand model schools (c) 
facilitate the formation of population corners and population-themed activities.

\section{REFERENCES}

Diniyati, L.S. and Jayatmi, I., 2017. Pengaruh Empat Variabel terhadap Perilaku Pernikahan Dini Perempuan Pesisir. Jurnal Ilmiah Kesehatan, 16(2), pp.14-22.

Hasanah, U. and Nadiroh, 2018. Buku Non Teks Pendidikan Kependudukan Integrasi dengan Mata Pelajaran di SMA-MA. 1st ed. Jakarta: Directorate of Population Education Cooperation National Board of Population and Family Planning.

Krisdayanti and Edyanto, 2018. Analisis Proses Mutasi Promosi Jabatan Pegawai Negeri Sipil di Kantor Badan Kepegawaian Daerah Kabupaten Gowa. Jurnal Noken, 3(1), pp.62-74.

Lahmi, A., 2016. Peranan Sekolah dalam Pendidikan Islam. ISTAWA:Jurnal Pendidikan Islam, 1(2), pp.121-138.

Ma'arif, F., 2018. Hubungan antara Tingkat Pengetahuan dan Sosial Budaya dengan Sikap Remaja Terkait Pendewasaan Usia Perkawinan. Jurnal Biometrika dan Kependudukan, 7(1), pp.39-48.

Marsuyetno and Harahap, R.H., 2013. Analisis Implementasi Kebijakan Pengelolaan Lingkungan Hidup di Sumatera Utara (Studi pada Badan Lingkungan Hidup Provinsi Sumatera Utara). Jurnal Administrasi Publik, 1(2), pp.271-292.

National Board of Population and Family Planning, 2015. Modul Pembekalan Guru SMA dalam Pengintegrasian Pendidikan Kependudukan Tahun 2015. [online] Jakarta: National Board of Population and Family Planning.

National Board of Population and Family
Planning, 2017. Pedoman Pengelolaan Pendidikan Kependudukan melalui Sekolah Siaga Kependudukan (SSK) di SMP, SMA dan Sederajat. Jakarta: National Board of Population and Family Planning

Nurulwahida, A.A., Makhsin, M.B., Azman, A. and Mokhtar, B., 2015. Soft Skills through Thinking Intelligence to Increase Employability Graduates. Australian Journal of Basic and Applied Sciences, 9(13), pp.12-18.

Rohmatulloh, and Shalahuddin, M. I., 2014. Pengembangan Model Logika Evaluasi Program Pengembangan SDM Responsif Gender Bidang ESDM. Jurnal Teknik Industri, 15(2), pp.145-153.

Sabdaningtyas, L., 2018. Model Evaluasi Implementasi Kebijakan Standar Pelayanan Minimal pada Satuan Pendidikan Jenjang SD. Jurnal Penelitian dan Evaluasi Pendidikan, 22(1), pp.70-82.

Titisari, A.S., 2018. Tren Pengetahuan Sikap dan Perilaku (PSP) Remaja terhadap Isu Kependudukan. Piramida: Jurnal Kependudukan dan Pengembangan Sumber Daya Manusia, [online] XIV(1), pp.16-22.

Yuliani, S. and Nadiroh, 2018. Buku Non Teks Pendidikan Kependudukan Integrasi dengan Mata Pelajaran di SMP-MTs. Jakarta: Directorate of Population Education Cooperation National Board of Population and Family Planning.

Zimmerman, M.A., Stoddard, S.A., Eisman, A.B., Caldwell, C.H., Aiyer, S.M., Miller, A., Caldwell, H., Aiyer, S.M. and Miller, A., 2013. Adolescent Resilience: Promotive Factors That Inform Prevention. Child Develompent Perspective, 7(4), pp.215-220. 